\title{
ANALISIS PERAN PPATK SEBAGAI SALAH SATU LEMBAGA DALAM MENANGGULANGI MONEY LAUNDERING DI INDONESIA
}

\author{
Toetik Rahayuningsih \\ toetik_rahayu@fh.unair.ac.id \\ Fakultas Hukum Universitas Airlangga
}

\begin{abstract}
The promulgation of the Law No. 8 Year 2010 on the Prevention and Eradication of Money Laundering creates a fundamental advancement of law enforcement in the field of criminal law. The fundamental change includes; broader change of the authority of PPATK to investigate suspicious transactions, blocking delay transaction, recommend surveillance, enforce of administrative sanctions, and conducta joint cooperation on anti money laundering and asset returnsas results of a criminal offence. By the authority PPATKwill be able to maximize its role as focal point in the prevention and eradication of the crime of money laundering and be able to strengthen the cooperation in the event when the suspect rushed out of the country. In the asset recovery program, PPATK plays important role especially in terms of financial information intelligence for the purposes of assets tracing, both on the analysis, and the investigation, prosecution and proceedings in the court.
\end{abstract}

Keywords: authority of PPATK, combating money laundering.

\begin{abstract}
Abstrak
Dalam perkembangan pengaturan pencucian uang di Indonesia telah dilakukan perubahan yang mendasar dengan diundangkannya UU PPTPPU.Perubahan mendasar diantaranya diaturnya kewenangan PPATK yang lebih luas dibandingkan dengan undang-undang sebelumnya, meskipun bukan kewenangan penyidikan. Beberapa kewenangan baru, yaitu: pemeriksaan dan penghentian sementara transaksi, merekomendasi penyadapan, melakukan perturan informasi, melakukan kerjasama dalam dan luar negeri baik bilateraql maupun multilateral. PPATK memiliki peran penting dan strategis dalam program assets recovery terutama dalam hal pemberian informasi intelijen di bidang keuangan untuk keperluan penelusuran aset (assets tracing).Pengaturan Model penindakan yang dapat diterapkan PPATK sangat terkait dengan kewenangannya menjatuhkan sanksi administratif oleh PPATK.
\end{abstract}

Kata kunci: kewenangan PPATK, penanggulangan pencucian uang. 


\section{Pendahuluan}

Pusat Pelaporan dan Analisis Transaksi Keuangan (PPATK) sebagai Financial Intelligence Unit (FIU) di Indonesia memiliki peran penting dalam penelusuran aset hasil kejahatan melalui pendekatan follow the money. Peran penting dan strategis PPATK dalam program assets recovery terutama dalam hal pemberian informasi intelijen di bidang keuangan untuk keperluan penelusuranaset (assets tracing), baik padawaktu proses analisis transaksi keuangan maupun pada saat proses penyidikan, penuntutan dan pemeriksaan terdakwa di sidang peradilan.

Penelusuran aset hasil tindak pidana dapat dilakukan oleh PPATK baik di dalam maupun di luar negeri melalui kerjasama dan koordinasi.Penelusuran aset di dalam negeri dilakukan dengan bekerjasama dengan penyedia jasa keuangan (PJK bank dan non bank) serta penyedia jasa/barang lainnya. Dalam rangka penanggulangan tindak pidana pencucian uang, PJK dan penyedia jasa/barang lainnya sebagai garis depan untuk melakukan deteksi secara dini terhadap seluruh transaksi yang mencurigakan melalui sistem keuangan untuk selanjutnya dilaporkan kepada PPATK.

Dalam rangka penyelamatan aset hasil tindak pidana secara dini, dengan kewenangannya untuk itu ada pada penyidik, penuntut umum atau hakim untuk memerintahkan PJK dan penyedia jasa/barang lainnya melakukan pemblokiran sementara terhadap harta kekayaan setiap orang atau perusahaan yang telah dilaporkan oleh PPATK. PJK dan penyedia jasa/barang lainnya setelah menerimaperintah, wajib melaksanakan pemblokiran sementara setelah surat perintah pemblokiran diterima.

Untuk menelusuri aset hasil kejahatan yang ditempatkan pelaku tindak pidana di luar negeri dilakukan dengan kerjasama antar sesama FIU maupun melalui kerjasaa bilateral maupun multilateral, melalui tukar menukar informasi. Manfaat pertukaran informasi antar sesama FIU ini,diantaranya mendapatkan hasil yang lebih cepat apabila dibandingkan dengan mekanisme tukar-menukar informasi melalui jalur yang lain.

Pertukaran informasi antar sesama FIU ini dapat dilakukan baik atas dasar Memorandum of Understanding (MoU) ataupun resiprositas, dengan menggunakan norma-norma yang diatur oleh Egmont Group atau sesuai dengan ketentuan yang ada dalam MoU. Norma tersebut mengatur tata cara pertukaran informasi yang bersifat rahasia, tidak diperbolehkan untuk diteruskan ke pihak lain, serta tidak dapat dijadikan sebagai barang bukti di pengadilan, dimana permintaan atau pemberian informasi tersebut dapat dibuat dalam bentuk tertulis atau elektronis. Keunggulan FIU dalam mendapatkan informasi yang lebih cepat danakurat ini adalah suatu hal yang seharusnya dapat dimanfaatkan secara optimal oleh para penegak hukum, untuk dapat mengamankan dan mengembalikan harta kekayaan negara dari para pelaku kriminal.Indonesia telah mendapat manfaat dari kerjasama antar FIU dalam rangka mengembalikan harta kekayaan negara (assets recovery) pada beberapa kasus kriminal yang menimbulkan kerugian negara yang cukup besar dan menjadi sorotan publik. Seperti pada kasus korupsi Hendra Raharja, 
pemerintah Australia akhirnya bersedia mengembalikan asset mantan pemilik Bank Harapan Sentosa (BHS) tersebut kepada pemerintah Indonesia sebesar 493.000 dollar Australia.

Dalam era teknologi informasi seperti sekarang ini, perputaran transaksi uang dan pengiriman uang lintas negara dapat dilakukan dalam hitungan menit, dengan sarana transaksi perbankan lewat internet (net banking atau e-banking). Sehingga perputaran uang yang cepat ini turut menjadi kendala penyelesaian LKTM. Seharusnya perputaran transaksi perlu dibekukan segera jika dicurigai merupakan transaksi keuangan ilegal. Sebagai contoh bank di Swiss diberikan kewenangan untuk menunda selama tiga hari pencairan uang suatu pengiriman uang sampai diperoleh kejelasan aliran dana yang masuk dan keluar tersebut.

Berkaitan dengan kemampuan untuk mendeteksi dugaan terjadinya money laundering, PPATK tidak hanya dapat melacak jejak harta kekayaan sebagai hasil kejahatan yang ditempatkan dalam sistem keuangan terkait proses pencucian uang, tapi juga menghentikan dan berupaya melakukan kerjasama dengan instansi terkait dalam rangka mengambil kembali sebagai aset negara yang ditelah diambil pelaku.

Melalui tiga tahapan placement atau penempatan, layering atau pemecahan/transfer dan integration atau menyatukan kembali harta kekayaan hasil kejahatan yang tersebar, biasanya dilakukan pelaku untuk mengaburkan, menyamarkan dan menyembunyikan hasil kejahatan agar tidak terldeteksi dan terlacak aparat penegak hukum. Adakalanya dalam upaya melancarkan aksinya pelaku pencucian uang seringkali bersekongkol dengan pihak-pihak lain seperti: pejabat lembaga keuangan, pejabat/pegawai bank, pengacara, akuntan, atau profesional lainnya. Keterlibatan pihak-pihak tersebut tentu saja dapat melancarkan upaya pelaku untuk "memutihkan uangnya", tanpa terdeteksi aparat penegak hukum. Pihak lain ini umumnya ditugaskan sebagai perantara untuk membuat rekening baik di dalam maupun luar negeri untuk menyembunyikan atau mengaburkan asal-usul harta kekayaan si pelaku.

PPATK sebagai pusat pelaporan telah bekerja keras untuk membangun rezim anti money laundering, bahkan diawal pembentukannya yang ingin mencontoh kinerja Austrac (Model Australia). Dalam perkembangannya PPATK belum cukup mampu menanggulangi aktivitas money laundering di Indonesia. Tuntutan berbagai pihak untuk memberikan kewenangan PPATK lebih besar telah menunjukkan betapa lembaga ini membutuhkan legitimasi sebagai lembaga yang bukan hanya sebagai pusat pelaporan semata, tetapi sebagai aparat penyidik untuk tindak pidana pencucian uang di samping Polri dan KPK. Hal ini juga dikarenakan sulitnya pembuktian tindak pidana ini.

Kemampuan aparat penegak hukum yang ada belum mendukung penegakan hukum, terbukti banyaknya temuan PPATK yang tidak ditindaklanjuti oleh aparat penyidik dengan alasan minimnya alat bukti. Selama ini hasil laporan yang diterbitkan oleh PPATK tidak mempunyai kekuatan sebagai alat bukti, sehingga tidak dapat digunakan sebagai alat bukti di pengadilan. Tentu saja hal ini adalah suatu kesia-siaan dan ketidak efektifan kinerja PPATK dalam melakukan suatu analisis transaksi keuangan, karena pada akhirnya yang menjadi 
penentu apakah diteruskan atau tidak perkara pencucian uang sangat tergantung oleh aparat penyidik Polri.

Berdasarkan latar belakang tersebut di atas diajukan permasalahan sebagai berikut: perluasan kewenangan apa saja yang perlu diberikan kepada PPATK dalam rangka mamaksimalkan kinerjanya untuk pencegahan dan pemberantasan tindak pidana pencucian uang dan model penindakan seperti apakah yang dapat dilakukan oleh PPATK atas pelanggaran pelaporan yang dilakukan oleh Penyedia Jasa Keuangan agar dapat dipastikan dipenuhinya kewajiban yang dibebankan kepadanya dalam rangka mengantisipasi terjadinya pencucian uang (money laundering) menggunakan sarana lembaga tersebut

\section{Pembahasan}

Upaya dan langkah strategis untuk lebih memberdayakan rezim anti pencucian uang di Indonesia sekarang dan di masa-masa mendatang, maka upaya yang harus dilakukan adalah memperkuat enam pilar utama yang satu sama lain sangat erat kaitannya. Pertama, hukum dan peraturan perundang-undangan. Kedua, sumber daya manusia dan sistem teknologi informasi. Ketiga, analisis dan kepatuhan Penyedia Jasa Keuangan. Keempat, kerjasama domestik dan internasional. Kelima, kelembagaan. Keenam, penelitian dan pengembangan. Penguatan rezim anti pencucian uang merupakan satu keharusan. Dalam hal ini dilaksanakan dengan memperkuat 6 (enam) pilar utama yang satu sama lain saling berkaitan erat. Strategi Nasional Pencegahan dan Pemberantasan TPPU telah disusun untuk rentang waktu 5 (lima) tahun kedepan (20072011). Ditujukan untuk mengenali kelemahan dalam pelaksanaan Rezim Anti Pencucian Uang yang membutuhkan tindakan penyelesaian yang representatif ditingkat eksekutif dan legislatif. Strategi Nasional ini merekomendasikan langkah-langkah strategis dalam berbagai bidang, yaitu: 1) pembuatan single identiy number (nomor identitas tunggal) bagi semua warga negara Indonesia untuk memudahkan pencegahan dan pemberantasan tindak pidana; 2) pengundangan rancangan Undang-Undang Pencegahan dan Pemberantasan Tindak Pidana Pencucian Uang secepatnya agar Indonesia memiliki undang-undang anti pencucian uang yang lebih komprehensif dan efektif untuk mencegah dan memberantas tindak pidana pencucian uang yang sesuai dengan standar internasional; 3) pengelolaan database secara elektronis dan connectivity (ketersambungan) database antar instansi terkait agar kebutuhan informasi setiap instansi terkait dapat terpenuhi secepatnya, sehingga penanganan tindak pidana pencucian uang dan tindak pidana lainnya menjadi lebih efektif dan efisien; 4) peningkatkan pengawasan kepatuhan penyedia jasa keuangan agar penyedia jasa keuangan memiliki kesadaran yang lebih tinggi untuk memenuhi kewajibannya sebagai pihak pelapor; 5) mengefektifkan penerapan penyitaan aset (aset forfeiture) dan pengembalian aset (asset recovery) agar harta kekayaan hasil kejahatan yang kembali ke negara dapat lebih maksimal dan sekaligus dapat memberikan konstribusi yang signifikan bagi pembanguan perekonomian nasional; 6) pengikatkan peran serta masyarakat melalui kampanye publik untuk mendukung pelaksanan rezim anti pencucian 
uang di Indonesia; 7) percepatan ratifikasi dan harmonisasi perjanjian internasional; 8) penguatan pengaturan tentang jasa pengiriman uang alternatif (Alternative Remittance System) dan pengiriman uang secara elektronis (wire transfer).

Rencana Strategi dan strategi penguatan rezim anti pencucian uang tersebut di atas merupakan kerangka acuan dan pedoman yang hendak dilakukan dan akan dituju dalam upaya penanggulangan tindak pidana pencucian uang di Indonesia dalam kurun waktu 2007-2011. Dengan acuan tersebut akan dapat dievaluasi kinerja keberhasilan maupun kendala yang diadapi untuk selanjutnya akan dilakukan perbaikan-perbaikan strategi ke depan dalam memaksimalkan pencegahan dan pemberantasan tindak pidana pencucian uang.

Pembentukan UU Nomor 8 Tahun 2010 tentang Pencegahan dan Pemberantasan Tindak Pidana Pencucian Uang (selanjutnya disingkat UU PPTPPU) dalam rangka memenuhi kepentingan nasional dan penyesuaian dengan standar internasional diharapkan menjadi landasan hukum untuk menjamin kepastian hukum, efektifitas penegakan hukum dan penelusuran dan pengembalian harta kekayaan hasil tindak pidana. Substansi baru yang diatur di dalam UU PPTPPU adalah: 1) redefinisi pengertian hal yang terkait dengan tindak pidana Pencucian Uang; 2) penyempurnaan kriminalisasi tindak pidana Pencucian Uang; 3 ) pengaturan mengenai penjatuhan sanksi pidana dan sanksi administratif; 4) pengukuhan penerapan prinsip mengenali Pengguna Jasa; 5)perluasan Pihak Pelapor; 6) penetapan mengenai jenis pelaporan oleh penyedia barang dan/ataujasa lainnya; 7) penataan mengenai Pengawasan Kepatuhan; 8) pemberian kewenangan kepada Pihak Pelapor untuk menundaTransaksi; 9) perluasan kewenangan Direktorat Jenderal Bea dan Cukai terhadap pembawaan uang tunai dan instrumen pembayaran lain ke dalam atau ke luar daerah pabean; 10) pemberian kewenangan kepada penyidik tindak pidana asal untuk menyidik dugaan tindak pidana Pencucian Uang; 11) perluasan instansi yang berhak menerima hasil analisis atau pemeriksaan PPATK; 12) penataan kembali kelembagaan PPATK; 13) penambahan kewenangan PPATK, termasuk kewenangan untukmenghentikan sementara Transaksi; 14) penataan kembali hukum acara pemeriksaan tindak pidana PencucianUang; dan; 15) pengaturan mengenai penyitaan Harta Kekayaan yang berasal daritindak pidana.

Substansi baru yang cukup banyak diatur dalam UU PPTPPU, di antaranya adalah penantaan kelembagaan PPATK, perluasan instansi yang berhak menerima hasil analisis atau pemeriksaan PPATK, serta penambahan kewenangan PPATK termasuk kewenangan untuk menghentikan sementara transaksi. Untuk lebih memperjelas peran PPATK yang diatur dalam UUPPTPPU, akan dibahas berikut ini.

Dalam UU PPTPPU, kedudukan PPATK diatur dalam Pasal 37, bahwa kedudukannya bersifat independen dan bebas dari campur tangan dan pengaruh kekekuasaan manapun, bertanggung jawab kepada Presiden. Pasal 38 PPATK berkedudukan di ibukota NKRI (Jakarta), dalam hal diperlukan dapat dibuka perwakilan di daerah. Tugas dan wewenangnya diatur dalam Pasal-pasal 39-46 UUPPTPPU, dan sebagai bentuk akuntabilitas PPATK, Pasal 47 menetapkan, 
PPATK membuat dan menyampaikan laporan pelaksanaan tugas, fungsi dan wewenangnya secara berkala setiap 6(enam) bulan, dan laporan tersebut disampaikan kepada Presiden dan DPR. Sebagai amanat ketentuk Pasl 46 UU PPTPPU, tatacara pelaksanan kewenangan PPATK diatur dengan Peraturan Presiden. Peraturan dimaksud adalah Peraturan Presiden Nomor 50 Tahun 2011, yang menggantikan kedudukan Kepres Nomor 82 Tahun 2003. Beberapa penambahan kewenangan akan dibahas lebih lanjut di bawah ini.

Menurut Pasal 1 angka 2 "Pusat Pelaporan dan Analisis Transaksi Keuangan yang selanjunta disingkat PPATK adalah lembaga independen yang dibentuk dalam rangka mencegah dan memberantas tindak pidana pencucian uang". Larangan bagi setiap orang yang melakukan campur tangan atas pelaksanaan tugas dan wewenang PPATK sebagaimana dimaksud Pasal 37 ayat(3), yang dapat diancam dengan pidana penjara paling lama dua tahun dan denda paling banyak Rp 500 juta (Pasal 14 UUPPTPPU). Selanjutnya menurut Pasal 15, Ancaman pidana yang sama juga dapat diterapkan pada pejabat PPATK yang melanggar kewajiban sebagaimana ditetukan Pasal 37 ayat (4). Pasal 16, mengatur sanksi yang cukup berat dalam hal Pejabat, pegawai PPATK, Penyidik, Penuntut Umum atau Hakim yang menangani perkara TPP yang sedang diperiksa, melanggar ketentuan Pasal 83 ayat (1) dan/atau Pasal 85 ayat(1) dipidana dengan pidana penjara paling lama 10 tahun.

Sesuai dengan tugas yang diemban, produk utama yang dihasilkan adalah berupa Hasil Analisis serta Hasil Pemeriksaan yang diharapkan dapat dijadikan dasar bagi aparat penegak hukum dalam melakukan proses penegakan hukum sesuai dengan tugas dan kewenangannya dan ketentuan yang berlaku. Direktorat Riset dan Analisis selalu berupaya meningkatkan kualitas dari setiap hasil analisis yang dihasilkan dan diharapkan hasil analisis yang disampaikan kepada aparat penegak hukum mampu memberikan informasi yang relevan atas kemungkinan terjadinya tindak pidana asal ataupun dilakukannya upaya penegakan hukum atas tindak pidana pencucian uang yang diduga dilakukan oleh pihak terlapor.Khusus terkait dengan Hasil Pemeriksaan, saat ini PPATK dalam tahap penyelesaian pembuatan Peraturan Presiden terkait dengan pelaksanaan kewenangan PPATK sebagaimana diamanatkan berdasarkan Pasal 46 UU PPTPPU.

Sebagai anggota komunitas FIU, keberadaan PPATK tidak dapat dilepaskan dari keberadaan UU PPTPPU, maupun UU sebelumnya. Keberhasilan yang telah dicapai dalam membangun anti pencucian uang di Indonesia belum cukup, dikarenakan kendala pengaturan terhadap institusi tersebut. Meskipun dalam perjalanannya sangat besar kontribusi yang telah diberikan lembaga ini dalam kerangka penegakan hukum dalam penanganan kasus pencucian uang di Indonesia. Sementara keterbatasan regulasi yang terkait dengan pengaturan kelembagaan, dirasakan membuat lembaga ini tidak dapat memaksimalkan peran dan fungsinya.Sementara itu maraknya kasus-kasus pencucian uang yang terjadi akhir-akhir ini sangat meresahkan masyarakat. Kelemahan dalam perundang-undangan inilah yang dimanfaatkan pelaku untuk tidak takut melakukan tindak pidana pencucian uang. Bahkan pelaku dengan sengaja membawa lari hasil kejahatan ke luar negeri supaya tidak dapat tersentuh aparat penegak hukum. Kenyataan 
inilah yang kemudian membuat pemerintah untuk sesegera mungkin memperbaiki ketentuan yang ada. Sementara ketentuan baru yang membutuhkan ketentuan pendukung, juga belum sesegera mungkin direalisir.Sehingga yang terjadi undang-undang yang baru seakan-akan tidak mampu menghadapi persoalan yang semakin kompleks.

Kerjasama yang menjadi sebuah solusi dalam pencegahan dan pemberantasan tindak pidana pencucian uang, memang banyak mengalami kendala teknis dalam pelaksanaannya. Sehingga kerjasama yang selama ini terjadi hanya bersifat formalitas dan belum menunjukkan ke arah meningkatnya penanganannya tindak pidana pencucian uang. Hal ini dapat dilihat dari keberhasilan pengembalian asset ke tanah air yang selama ini diusahakan oleh pemerintah melalui jalur kerjasama dengan luar negeri. Banyak aset-aset yang ditempatkan di luar negeri yang tidak mampu di bawa kembali ke tanah air dengan alasan karena perbedaan sistem hukum, dan ketidak mampuan diplomasi pemerintah Indonesia dengan pemerintah negara dimana aset di tempatkan.

Dalam rangka mendeteksi tindak pidana pencucian uang UU PPTPPU menciptakan beberapa kewajiban pihak pelapor (Pasal 17) yang disampaikan kepada PPATK, yaitu: a) Laporan transaksi yang mencurigakan yang disampaikan oleh penyedia jasa keuangan (ps.1 angka 5, 6 dan Pasal 23UU PPTPPU); b) Laporan yang disampaikan oleh penyedia jasa keuangan tentang transaksi keuangan yang dilakukan secara tunai dalam jumlah kumulatif lima ratus juta rupiah. (Pasal 23 ayat (1) huruf b UU PPTPPU); c) Transaksi keuangan transfer dana dari dank e luar negeri(Pasal 23 ayat (1) huruf c).

Atas dasar laporan tersebut dan informasi lainnya. PPATK melakukan analisa, (mendeteksi tindak pidana pencucian uang) kemudian menyerahkan laporan hasil analisisnya kepada pihak Penyidik dan Penuntut. Untuk memperoleh laporan dan hasil deteksi atau analisa yang baik PPATK harus menjalin kerjasama yang baik dengan penyedia jasa keuangan dan instansi terkait lainnya atau dengan FIU dari negara lain. Selanjutnya dalam proses penegakan hukum, PPATK dapat melakukan kerjasama dan membantu pihak penyidik dan penuntut umum dengan informasi yang dimiliki dan kemampuan analisisnya. Informasi tersebut dapat berasal dari data base PPATK atau dapat juga berasal dari sharing information dengan FIU dari negara lain.

Sebagai salah satu tugas pokok PPATK, melakukan analisis atas transaksi keuangan mencurigakan yang disampaikan oleh Penyedia Jasa Keuangan/PJK kepada PPATK.Kegiatan ini merupakan hal penting untuk dilaksanakan dengan memanfaatkan seluruh sumber daya yang dimiliki oleh PPATK. Pelaksanaan analisis oleh PPATK dilaksanakan dengan mendapatkan data/informasi dari PJK, bantuan kerjasama dengan Financial Intelligence Unit di luar negeri serta aparat penegak hukum di Indonesia.

Dalam rangka melaksanakan fungsi analisis sebagaimana diatur Pasal 44 UU PPTPPU (lihat tabel). Penyedia Jasa Keuangan harus segera menindaklanjuti setelah menerima permintaan dari PPATK. Selanjutnya menurut Pasal 48 Perpres Nomor 50 Tahun 2011, PPATK 
meneruskan Hasil analisis yang berindikasi TPPU atau tindak pidana lain kepada penyidik atas dasar inisiati sendiri maupun permintaan penyidik, dan dalam hal menindaklanjuti hasil analisis tersebut penyidik melakukan koordinasi dengan PPATK, perlu ditegaskan bahwa Penerusan hasil analisis atau hasil pemeriksaan yang dilakukan baik secara elektronis maupun nonelektronis. Penyidik wajib menjaga kerahasiaan hasil analisis atau hasil pemeriksdaan yang disampaikan oleh PPATK (Pasal 50 Perpres Nomor 50 Tahun 2011)

Berikut ini dikemukakan proses analisis yang dilakukan PPATK dalam membantu aparat penegak hukum untuk memberikan informasi dugaan transaksi keuangan mencurigakan untuk selanjutnya dapat ditindaklanjuti oleh aparat penegak hukum untuk melakukan proses penyidikan, penuntutan hingga pemeriksaan di muka pengadilan.

Proses Analisis oleh Analis PPATK

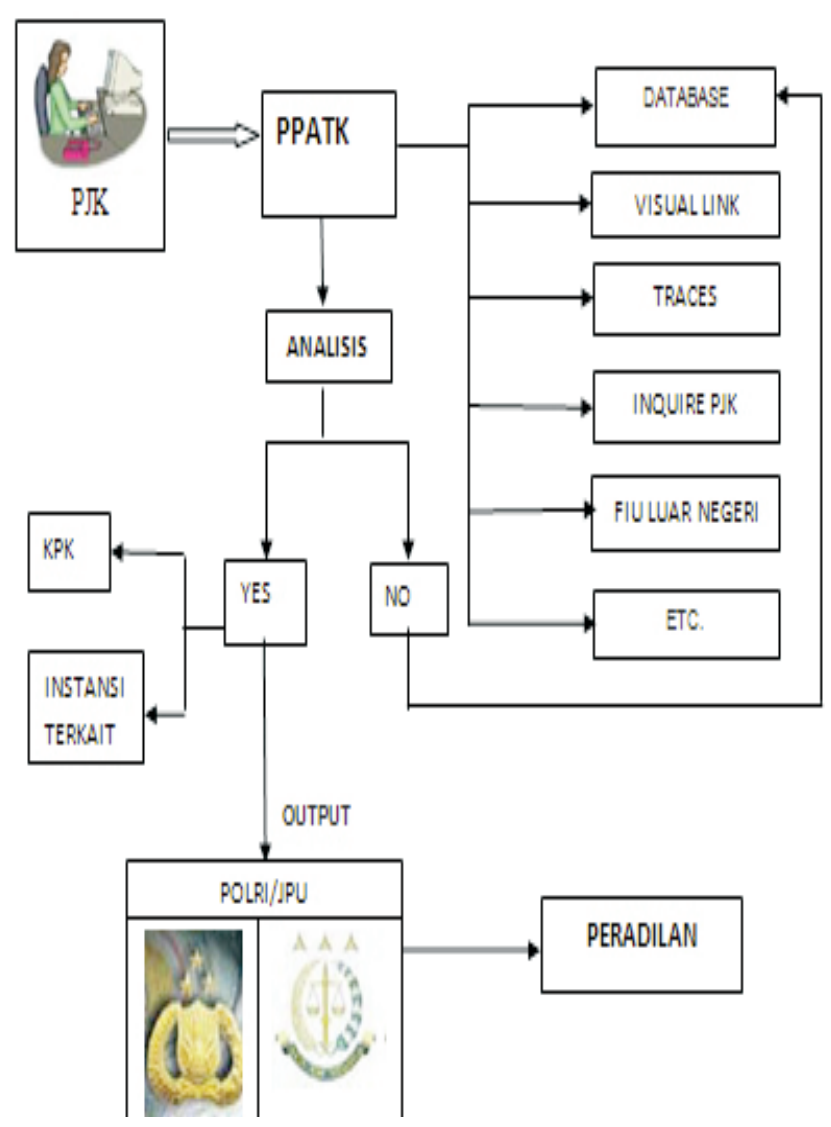

Sumber: Laporan Tahunan PPATK2009

Kepala PPATK menjelaskan semakin meningkatnya trend transaksi tunai diduga antara lain dengan maksud untuk memutus pentrasiran atau pelacakan asal-usul sumber dana dan memutus pelacakan aliran dana kepada pihak penerima dana (beneficiary) yang pada akhirnya akan mempersulit tugas PPATK dalam melakukan analisis transaksi keuangan mencurigakan. ${ }^{1}$

1 “Terjadi Pergeseran Kebiasaan Transaksi Menjadi Tunai”, www.ppatk.go.id, diunduh", 12 September 2011. 
Sebagai amanat Pasal 46 UU PPTPPU, sejak 12 Agustus 2011 telah diterbitkan Peraturan Presiden yang mengatur tentang Tatacara Pelaksanaan Kewenangan PPATK. Peraturan ini terdiri dari VII bab, dan 54 pasal, yang kesmuanya terkait dengan pelaksanaan wewenang PPATK. Berdasarkan Pasal 3 Perpres Nomor 50 Tahun 2011, PPATK berwenang : a) meminta, mendapatkan data dan informasi dari instansi pemerintah dan/atau lembaga swasta yang memiliki wewenang memiliki data dan informasi; b) menetapkan pedoman identifikasi Transaksi Keuangan Mencurigakan; c) mengkoordinasikan upaya pencegahan dan pemberantasan TPPU dengan instansi terkait; d) memberikan rekomendasi kepada pemerintah, upaya pencegahan danpemberantasan TPPU; d) mewakili pemerintah RI dalam organisasi dan forum internasional yang berkaitan dengan TPPU; e) menyelenggarakan program pendidikan dan latihan anti pencucian uang dan; f) menyelenggarakan sosialisasi pencegahan dan pemberantasan TPPU.

Dalam rangka melaksanakan fungsi analisis atau pemeriksaan dan informasi sebagaimana dimaksud dalam Pasal 40 huruf d, PPATK dapatmerekomendasikan kepada instansi penegak hukum mengenai pentingnya melakukan intersepsi atau penyadapan atas informasi elektronik dan/atau dokumen elektronik sesuai dengan ketentuan peraturan perundang-undangan (Pasal 44 UU PPTPPU). Lebih lanjut, kewenangan penyadapan, Pasal 39 Peraturan Presiden Nomor 50 Tahun 2011 tentang Tata Cara Pelaksanaan Kewenangan Pusat Pelaporan dan Analisis Transaksi Keuangan (Perpres No. 50/2011) menyatakan PPATK dapat merekomendasikan pentingnya penyadapan pada kepada instansi penegak hukum atas informasi elektronik dan/atau dokumen elektronik sesuai dengan ketentuan peraturan perundang-undangan.

Rekomendasi disampaikan oleh Kepala PPATK pada pimpinan instansi penegak hukum. Kemudian, lembaga penerima rekomendasi PPATK wajib memberi tanggapan. Selanjutnya, hasil pengolahan intersepsi atau penyadapan disampaikan kepada PPATK sepanjang tidak bertentangan dengan ketentuan peraturan perundang-undangan. Hasil pengolahan intersepsi atau penyadapan adalah bersifat rahasia. ${ }^{2}$ Kewenangan baru PPATK yang disyaratkan dalam Perpres No. 50/2011, disebutkan dalam Pasal 37, yaitu: PPATK dapat menerima laporan dan/atau informasi dari masyarakat mengenai adanya dugaan tindak pidana pencucian uang. Laporan dapat disampaikan secara elektronis maupun non-elektronis. Oleh PPATK, laporan masyarakat tersebut dapat ditindaklanjuti lalu mengembangkan laporan dan/atau informasi yang diterima; atau menempatkan laporan dan/atau informasi ke dalam basis data PPATK.Laporan tersebut wajib dirahasiakan oleh PPATK. Mengenai permintaan keterangan, Perpres menyatakan PPATK dapat meminta keterangan kepada pihak pelapor dan pihak lain yang terkait dengan dugaan tindak pidana pencucian uang. Disebutkan dalam Pasal 38 Perpres No. 50/2011, permintaan keterangan dilakukan secara langsung, dan/atau permintaan keterangan secara tidak langsung. Mengenai permintaan keterangan secara langsung, PPATK dalam melakukan dengan cara audit

2 "PPATK Jadi Pintu Permintaan Informasi," http://www.hukumonline.com/berita/baca/lt4e55f8fdee222/ ppatk-jadi-pintu-permintaan-informasi, diunduh 11 Oktober 2011. 
khusus terhadap pihak pelapor. Atau, meminta kehadiran pihak pelapor dan pihak lain, dan/atau menggunakan sarana komunikasi.Permintaan keterangan secara tidak langsung, dapat dilakukan dengan bantuan Lembaga Pengawas dan Pengatur atau pihak terkait.

Periode 2010 PPATK telah melakukan pertukaran informasi dengan FIU-FIU negara lain. Adapun rincian dari pertukaran informasi tersebut di antaranya adalah meneriman permintaan informasi sebanyak 49 kali, mengirimkan permintaan informasi sebanyak 5 kali, menerima informasi spontan sebanyak 11 kali, dan mengirimkan informasi spontan sebanyak 1 kali. Hingga akhir tahun 2010, jumlah kumulatif pertukaran informasi dengan pihak FIU adalah 406 kali. Pertukaran informasi tersebut dilaksanakan dengan FIU-FIU negara lain, dan sebagaimana tampak pada tabel di atas, pertukaran informasi intelijen keuangan tersebut dilakukan permintaan dan sukarela.

Terkait dengan pertukaran informasi keuangan dengan instansi domestik, Kelompok Pemberdayaan Jejaring Informasi telah menindaklanjuti permintaan dari Kepolisian, KPK, Kejaksaan, dan instansi-instansi terkait lainnya. Adapun jumlah permintaan informasi sepanjang tahun 2009 yaitu dari: Polri sebanyak 184 permintaan, KPK sebanyak 25 permintaan; Kejaksaan sebanyak 7 permintaan; dan instansi terkait lainnya sebanyak 22 permintaan. Jumlah permintaan informasi kumulatif untuk instansi-instansi tersebut di atas dari tahun 2004 hingga Desember 2009 adalah: Polri sebanyak 526 permintaan, KPK sebanyak 244 permintaan, Kejaksaan sebanyak 69 permintaan, dan instansi lain-lain sebanyak 72 permintaan. Secara lebih lengkapnya dapat dilihat pada tabel statistik permintaan informasi ke PPATK. Selain menindaklanjuti seluruh permintaan informasi, Kelompok Pemberdayaan Jejaring Informasi PPATK juga telah melaksanakan program asistensi ke sejumlah Polda di Indonesia. Untuk tahun 2009 ini telah dilaksanakan 7 (tujuh) program asistensi yaitu ke Polda Sumatera Utara, Polda Sumatera Barat, Polda Jawa Tengah, Polda Jawa Barat, Polda Kalimantan Barat, Polda Sulawesi Utara, dan Polda Kalimantan Selatan. Melalui program asistensi tersebut, PPATK berkesempatan untuk menjelaskan mekanisme permintaan informasi ke PPATK serta membantu pihak Polda dalam hal penanganan kasus TPPU.

Periode 2010, Terkait dengan pertukaran informasi intelijen keuangan dengan instansi domestik, Kelompok Pemberdayaan Jejaring Informasi telah menindaklanjuti permintaan dari Kepolisian, KPK, Kejaksaan, dan instansi-instansi terkait lainnya.Adapun Jumlah kumulatif permintaan informasi yang ditindaklanjuti sampai dengan Desember 2010 adalah sebanyak 259 hasil analisis.Selain menindaklanjuti seluruh permintaan informasi, Kelompok Pemberdayaan Jejaring Informasi juga telah telah melaksanakan program asistensi ke sejumlah Polda di Indonesia. Untuk tahun 2010 ini telah dilaksanakan program asistensi ke Polda Kalimantan Timur, Polda Sulawesi Selatan, Polda NTB, Polda Jambi, Polda Jawa Timur, Polda Sumatera Utara dan Polda Aceh. Melalui program asistensi tersebut, PPATK berkesempatan untuk menjelaskan mekanisme permintaan informasi ke PPATK serta membantu pihak Polda dalam hal penanganan kasus, khususnya untuk kasus-kasus Tindak Pidana Pencucian Uang. 
Pada kurun waktu 2010, telah diadakan beberapa pertemuan ilmiah diantaranya, Expert Group Meeting yang dilaksanakan pada tanggal 22-24Februari 2010 di Jakarta. Pertemuan ini dihadiri oleh 11 (sebelas) perguruan tinggi di Indonesia yang menghasilkan masukan-masukan atas draft UU PPTPPU serta rekomendasi kepada pemerintah dalam mendorong percepatan pembahasan dan pengesahan UUPPTPPU.

Penandatanganan Nota Kesepahaman antara PPATK dengan beberapa instansi pemerintah diantaranya, dengan Bank Indonesia pada tanggal 18 Maret 2010 di Jakarta. Kerjasama melalui penandatanganan Nota Kesepahaman ini bertujuan untuk menetapkan upaya atau langkah-langkah pencegahan dan pemberantasan tindak pidana pencucian uang dalam hal pertukaran informasi, penyusunan ketentuan hukum, audit kepatuhan, sosialisasi serta pendidikan danpelatihan dalam hal adanya keterkaitan antara pelaksanaan tugas dan kewenangan Bank Indonesia dan PPATK.

Penandatanganan Nota Kesepahaman antara PPATK dengan Komisi Pengawas-an Persaingan Usaha (KPPU) pada tanggal 17 April 2010 di Jakarta. Kerjasama ini bertujuan untuk mewujudkan kerangka kerjasama antara KPPU dan PPATK dalam mencegah dan memberantas tindak pidana pencucian uang dan penegakan hukum atas larangan praktik monopoli dan persaingan usaha tidak sehat; Penandatanganan Nota Kesepahaman antara PPATK dengan Direktorat Jenderal Kesatuan Bangsa dan Politik, Kementerian Dalam Negeri serta Badan Pengawas Pemilupada tanggal 7 Juli 2010 di Jakarta.

Tujuan dilakukannya pertemuan ilmiah dan perluasan kerjasama dengan beberapa perguruan tinggi di Indonesia adalah dalam rangka mensosialisasikan rezim anti pencucian uang di Indonesia, dimana salah satu media sosialisasi adalah melalui pendidikan/edukasi. Sebagaimana ditetapkan dalam Konvensi PBB (UNTOC dan UNCAC) kerjasama merupakan suatu keharusan dalam memerangi tindak pidana pencucian uang. Masyarakat dunia sangat berkepentingan untuk diaturnya ketentuan yang terkait dengan kerjasama sebagai sarana untuk memerangi pencucian uang dan pengembalian aset hasil tindak pidana. Tanpa kerjasama bilateral maupun multilateral, suatu negara tidak akan mampu menyelesaikan persoalan yang terkait dengan pencucian uang. Anjuran PBB tersebut kemudian diimplementasikan ke dalam hukum nasional Indonesia, sebagaimana diatur dalam Pasal 88 - 90 UU PPTPPU.

Dalam kaitannya dengan kerjasama pencegahan dan pemberantasan tindak pidana pencucian uang, Undang-undang Nomor 1 Tahun 2006 tentang Perjanjian Internasional (UU No. 1/2006) telah memberikan acuan untuk Indonesia dalam hal melakukan kerjasama dengan negara lain, baik mengenai mekanisme maupun bentuk-bentuknya. Hal ini tentu saja akan melengkapi keberadaan ketentuan Pasal 88-90 UU PPTPPU dalam rangka memaksimalkan pengembalian aset hasil tindak pidana yang dilarikan pelakunya di luar negeri.

Dalam rangka mengoptimalkan peranan PPATK, Presiden RI Susilo Bambang Yudhoyono pada tanggal 12 Agustus 2011 telah menandatangani dan menetapkan Perpres No. 50/2011. Pembentukan Perpres dimaksud merupakan amanat atau ketentuan pelaksanaan dari 
Pasal 46UU PPTPPU.Pada pokoknya Perpres No. 50/2011 mengatur tata cara pelaksanaan kewenangan PPATK sesuai tugas dan fungsinya berdasarkan UU PPTPPU yang meliputi (i) pencegahan dan pemberantasan tindak pidana pencucian uang; (ii) pengelolaan data dan informasi yang diperoleh PPATK; (iii) pengawasan terhadap kepatuhan Pihak Pelapor; dan (iv) analisis atau pemeriksaan laporan dan informasi Transaksi Keuangan yang berindikasi tindak pidana pencucian uang dan/atau tindak pidana lain sebagaimana dimaksud dalam Pasal 2 ayat (1) UU PPTPPU. PPATK menyambut baik penetapan Perpres tersebut karena akan memberikan landasan hukum yang kuat dan lengkap bagi PPATK dalam mengimplementasikan UU TPPU yang baru.

Saat ini PPATK telah bekerjasama dengan (NLRP) Pemerintah Belanda dan didukung kerjasama dengan (IWGFF) telah menyusun Peraturan di bidang pencegahan National Legal Reform Program Indonesian Working Group on Forest Finance Regulatory Manual dan Pemberantasan Tindak Pidana Pencucian Uang (TPPU) danPendanaan Terorisme.yang disusun memuat ikthisar dan mensistematisasi ketentuan-ketentuan yang diatur dalam undang-undang, peraturan pemerintah, keputusan presiden, peraturan atau keputusan menteri, peraturan atau keputusan kapolri, peraturanatau keputusan jaksa agung, putusan pengadilan, peraturan Bank Indonesia (PBI), Surat Edaran Bank Indoensia (SEBI), Peraturan dan Keputusan Kepala PPATK,

PPATK sebagai instansi yang berperan dalam rezim anti pencucian uang di Indonesia, berupaya untuk terus meningkatkan hubungan dan kerjasama dengan instansi-instansi terkait dalam negeri maupun luar negeri. Jalinan kerjasama ini telah dilakukan dengan 41 instansi/ lembaga di dalam negeri dan 37 (FIU) negara-negara lain. Dalam rangka kerjasama luar negeri, secara aktif PPATK berperan dalam forum internasional sepertiAPG dan FATF. Kerjasama PPATK dengan FIU di luar negeri dilakukan dalam bentuk MoU maupun pertukaran informasi.

Selama tahun 2010, PPATK memperkuat hubungan dan kerjasama dalam negeri maupun luar negeri dengan melakukan Komite Nasional Pencegahan dan Pemberantasan Tindak Pidana Pencucian Uang dan Pendanaan Terorisme (KomiteTPPU\&PT). Pertemuan Tim Kerja Tindak Pidana Pencucian Uang dan Pendanan Terorisme telah dilaksanakan pada tanggal 27 Januari 2010 dan Pertemuan Komite TPPU yang diketuai oleh Menko Polhukkam MarsekalTNI (Pur) Djoko Suyanto pada tanggal 18 Maret 2010 pun telah diselenggarakan. Dalam pertemuan tersebut dibahas perkembangan implementasi Strategi Nasional Pencegahan dan Pemberantasan Tindak Pidana Pencucian Uang dan Pendanaan Terorisme. Selanjutnya akan diselenggarakan Pertemuan Tim Kerja Komite TPPU \& PT dan Pertemuan Komite TPPU dan PT tingkat menteri yang akan dipimpin kembalioleh Menko Polhukkam selaku Ketua Komite.

Di tahun 2010 PPAT $^{3}$ secara konsisten tetap turut aktif berperan dalam berbagai fora internasional, antara lain forum Asia Pacific Group on Money Laundering (APG) dan Financial Action Task Force (FATF). Dalam forum APG, PPATK menghadiri APG Annual Meeting yang diselenggarakan di Singapura, APG Assessor Training Workshop yang diselenggarakan

\footnotetext{
3 PPATK, Laporan Tahunan 2010, h. 8.
} 
di Sydney, Australia, dan APG Typologies Workshop yang diselenggarakan di Bangladesh. Selain itu PPATK telah aktif menjadi bagian dari misi APG ke Banglades untuk menyampaikan pengalaman mempersiapkan targeted review ICRG FATF serta ke Timor Leste untuk membantu upaya pembangunan rezim anti pencucian uang di negara tersebut. Sementara itu dalam forum the Egmont Group, PPATK mengirimkan wakilnya untuk mengikuti yang diselenggarakan di Mauritius dan Moldova masing-masing pada bulan Maret dan Oktober 2010, serta berpartisipasi aktif dalam Egmont Annual Meeting yang diselenggarakan di Cartagena, Colombia pada bulan Juni 2010. Selain itu PPATK secara aktif menjadi sponsor permohonan keanggotaan Solomon Islands FIU (SIFIU) dan Samoa FIU (SFIU) dalam Egmont Group. Setelah melaporkan perkembangan dan analisis awal atas legislasi untuk SIFIU dan SFIU pada pertemuan bulan Juni dan Oktober 2010, PPATK melakukan onsite visit ke Solomon Islands pada bulan November 2010 bersama dengan wakil AUSTRAC dan Cook Island FIU untuk memastikan bahwa SIFIU telah beroperasi secara penuh sebagai sebuah FIU. Onsite visit ke Samoa akan dilakukan pada bulan Januari 2011. Hasil onsite visit ke Solomon Islands dan Samoa akan dipaparkan pada pertemuan Egmont WG di Aruba bulan Maret 2011 dan diharapkan kedua FIU tersebut akan diterima pada pertemuan tahunan Egmont di Armenia bulan Juni 2011.

Seiring dengan kesadaran pihak pelapor yaitu penyedia jasa keuangan dan pembawaan uang tunai ke luar wilayah oleh Dirjen Bea dan Cukai, PPATK pada dasarnya hanya dapat menerima tiga jenis laporan: Laporan Transaksi Keuangan Mencurigakan (LTKM), Laporan Transaksi Keuangan Tunai (LTKT), dan Laporan Pembawaan Uang Tunai (LPUT).Peningkatan kesadaran tersebut nampak dari jumlah laporan yang diterima Selama 2010, Terhitung sejak tahun 2001 hingga akhir tahun 2010, PPATK telah menerima sebanyak 63.924 Laporan Transaksi Keuangan Mencurigakan (LTKM) secara kumulatif, dengan jumlah PJK Pelapor sebanyak334 PJK. PPATK juga telah menerima sebanyak 8.631.423 Laporan Transaksi. Keuangan Tunai (LTKT) secara kumulatif. Sejak tahun 2003 hingga akhir tahun2010, PPATK telah pula menyampaikan sebanyak 1.431 Hasil analisis secarakumulatif kepada Kepolisian dan Kejaksaan.Sementara dalam kurun tahun2010, PPATK telah menyampaikan sebanyak 319 Hasil Analisis kepada Kapolridan Jaksa Agung. Berdasarkanstatistik Hasil Analisis PPATK mendominasi dengan 580 kasus atau sekitar40,5\% hasil analisis PPATK. ${ }^{4}$

Dengan kewenangan menjatuhkan sanksi adminitratif dan merekomendasikan pencabutan izin usaha sebagaimana diatur dalam ketentuan di atas, diharapkan akan memberikan efek jera bagi pihak pelapor apabila mengabaikan dan melalaikan kewajiban pelaporan yang diatur dalam ketentuan perundang-undangan. Penerimaan denda administratif akan memberikan kontribusi pada Negara sebagai penerimaan Negara bukan pajak yang pada akhirnya akan dapat dikelola dan dimanfaatkan untuk kesejahteraan masyarakat. Selain itu, dalam penanganan kasus tindak pidana pencucian uang, intelijen mempunyai peran yang sangat penting serta merupakan

4 PPATK, Laporan Tahunan 2010, h. 18. 
informasi yang sangat dibutuhkan oleh para aparat penegak hukum. Sebagai Financial Intelligence Unit di Indonesia, PPATK akan selalu berupaya untuk memberikan informasi intelijen keuangan yang terpercaya dan dapat diandalkan sehingga diharapkan informasi tersebut nantinya dapat membantu aparat penegak hukum dalam menindaklanjuti suatu kasus tindak pidana pada umumnya dan atau kasus tindak pidana pencucian uang pada khususnya. ${ }^{5}$

Dengan demikian, upaya pencegahan dan pemberantasan kejahatan pencucian uang tidak mungkin dapat dilakukan oleh PPATK tanpa bantuan pihak lain. Dalam kaitan ini dukungan dan kerjasama seluruh pihak terutama industri keuangan khususnya perbankan, aparat penegak hukum (polisi, jaksa dan hakim), kalangan pers dan masyarakat luas sangat diperlukan.Pengawasan sektor keuangan dalam kaitannya dengan pelaksanaan UU TPPU oleh PPATK merupakan sektor strategis dalam upaya pencegahan dan pemberantasan tindak pidana pencucian uang. Pada satu sisi, PPATK sebagai focal point, memiliki akses yang luar biasa terhadap sistem keuangan sesuai dengan tugas dan kewenangan yang diberikan.

Saat ini, jumlah penyedia jasa keuangan dari berbagai jenis industri keuangan yang telah melapor (baik LTKM maupun LTKT ataupun keduanya) kepada PPATK sebanyak 123 jenis bank umum, 118 jenis perusahaan efek, 155 perusahaan asuransi, 144 perusahaan pembiayaan, 107 manajer investasi, 20 pedagang valuta asing, dan 10 BPR. Sampai dengan saat ini PPATK secara proaktif telah memanfaatkan database Egmont Group (Paguyuban FIU Sedunia). Selain itu, berkat dukungan Kapolri dan jajaran NCB Interpol Indonesia, PPATK telah dapat mengakses database yang dimiliki oleh jejaring NCB-Interpol Sedunia yang dikenal dengan I 24/7. Akses terhadap pusat-pusat data ini sangat penting untuk memperkaya dan mempertajam analisi PPATK terhadap transaksi keuangan mencurigakan.

Berbagai informasi tersebut kemudian direkonstruksikan oleh PPATK sehingga dapat dilihat keterkaitan antara berbagai transaksi sejumlah dana, orang terkait, sumber dana/perbuatan menghasilkan dana tersebut. Selanjutnya, informasi yang dihasilkan diteruskan kepada aparat penegak hukum, dalam hal ini Kepolisian, Kejaksaan maupun Komisi Pemberantasan Korupsi (KPK) untuk dilakukan penyelidikan, yang diteruskan dengan penyidikan dan proses peradilan.

Selain proses yang sifatnya bottom up berasal dari penyedia jasa keuangan, terdapat pula mekanisme top down yang dapat dimanfaatkan aparat penegak hukum dalam melakukan investigasi. Dalam hal ini, aparat penegak hukum dapat meminta informasi keuangan kepada PPATK untuk melengkapi informasi hasil operasi di lapangan. PPATK akan mencari informasi dari berbagai sumber, seperti database yang sudah ada, FIU negara lain jika diperlukan, serta meminta informasi berupa LTKM kepada penyedia jasa keuangan. ${ }^{7}$

\footnotetext{
5 Agus Triyono, "Tinjauan Undang-undang Tindak Pidana Pencucian Uang dan Penegakannya”, Makalah Seminar Dampak Operacional UU TPPU (Tindak Pidana Pencucian Uang) Pasca Amandemen di Bidang Perbankan, Jakarta: Guna Media Sinergy Consulting, 11 Oktober 2004.

6 Yunus Husein, "Rezim Anti Pencucian Uang: Peran Strategis dan Perkembangan Terkini” Makalah Kuliah Umum, Padang: Universitas Andalas, 18 Mei 2009, h.3.

7 Ibid.,h.2.
} 
Pendekatan rezim anti money laundering merupakan paradigma baru dalam mengejar hasil tindak pidana. Dengan pendekatan ini diharapkan semua hasil tindak pidana dapat dirampas untuk negara sehingga angka kriminalitas diharapkan berkurang dan sistem keuangan lebih stabil dan terpercaya.

Untuk melaksanakan fungsi pengawasan kepatuhan pihak pelapor, Pasal 13 Perpres No. 50/2011, PPATK berwenang: a. menetapkan ketentuan dan pedoman tatacara pelaporan bagi Pihak Pelapor; b. menetapkan kategori pengguna jasa yang berpotensi melakukan TPPU; c. melakukan audit kepatuhan atau audit khusus; d. menyampaikan informasi dari hasil audit kepada lembaga yang berwenang melakukan pengawasan; e.memberikan peringatran kepada pihak pelapor yang melanggar kewajiban pelaporan; f.merekomendasikan kepada lembaga yang berwenang mencabut ijin iusaha pihak pelapor dan, g. menetapkan ketentuan pelaksanaan prinsip mengenali pengguna jasa bagi pihak pelapor yang tidak memiliki lembaga pengawas dan pengatur. Hal menarik terkait dengan kewenangan PPATK, pada bagian kesembilan yaitu intersepsi dan penyadapan sebagaimana ditetapkan dalam Pasal 39 ayat (1), PPATK dapat merekomendasikan kepada instansi penegak hukum mengenai pentingnya dilaukan intersepsi atau penyadapan atas informasi elektronik dan/atau dokumen elektronik sesuai dengan ketentuan yang berlaku. (2) Rekomendasi tersebut disampaikan oleh kepala PPATK kepada pimpinan instansi penegak hukum; (3) instansi penegak hukum wjib memberikan tanggapan atas rekomendasi yang disampaikan kepala PPATK; (5) Hasil pengolahan intersepsi atau penyadapan disampaikan PPATK sepanjang tidak bertentangan dengan ketentuan perundangundangan yang berlaku. (6) Penyampaian hasil pengolahan intersepsi atau penyadapan bersifat rahasia.

\section{Kesimpulan}

Dalam perkembangan pengaturan pencucian uang di Indonesia telah dilakukan perubahan yang mendasar dengan diundangkannya UU PPTPPU. Perubahan tersebut dilakukan demi kepentingan nasional dengan penyesuaian standar internasional pencegahan dan pemberantasan tindak pidana pencucian uang. Perubahan mendasar diantaranya diaturnya kewenangan PPATK yang lebih luas dibandingkan dengan undang-undang sebelumnya, meskipun bukan kewenangan penyidikan. Beberapa kewenangan baru, yaitu: pemeriksaan dan penghentian sementara transaksi, merekomendasi penyadapan, melakukan perturan informasi, melakukan kerkasama dalam dan luar negeri baik bilateraql maupun multilateral. Dengan bertambahnya kewenangan PPATK yang diberikan undang-undang, diharapkan upaya pencegahan dan pemberantasan tindak pidana pencucian uang akan lebih optimal.

Pengaturan Model penindakan yang dapat diterapkan PPATK sangat terkait dengan kewenangannya menjatuhkan sanksi administratif oleh PPATK. Pengaturan yang cukup lengkap dan jelas mengenai jenis sanksi administratif maupun tatacara penerapannya, akan memudahkan dalam implemntasinya. Selanjutnya akan dapat memberikan kontribusi pendapatan negara yang 
diperoleh melalui penerimaan denda administratif yang disetor ke kas negara atas pelanggaran kewajiban pelaporan.akan yang dimiliki PPATK khususnya dalam pengembalian aset hasil kejahatan ke dalam negeri. Untuk lebih mengoptimalkan peran PPATK, seyogyanya lembaga ini benar-benar independen dan terbebas dari campur tangan semua pihak, agar hasil analisis yang dilakukan mempunyai nilai kepercayaan dan akuntabel. Sehingga menjadi lembaga yang disegani baik di dalam dan di luar negeri karena pengaruhnya yang luar biasa dalam membantu aparat penegak hukum untuk menelusuri aset hasil tindak pidana. Kemauan bersama untuk memerangi tindak pidana pencucian uang dengan mematuhi ketentuan hukum yang berlaku merupakan modal utama bagi pihak pelapor maupun setiap orang akan membantu negara kita untuk keluar dari persoalan korupsi dan kejahatan yang menghasilkan aset. Penegakan hukum yang sungguh-sungguh (penegakan sanksi administratif) akan memberikan efek jera bagi pelaku, baik yang telah melakukan dan menjadi aspek pencegahan bagi calon pelaku.

\section{Daftar Bacaan}

Amrullah, M.Arief., Tindak Pidana Pencucian Uang Money laundering, Cetakan Ketiga, Malang: Bayumedia Publishing, 2004.

Ariawan, I Gusti Ketut,"Stolen Asset Recovery Initiative, Suatu Harapan dalam Pengembalian Aset Negara", Kertha Patrika, Vol 33 No.1 Januari 2008.

Arief, Barda Nawawi, "Kebijakan Formulasi UUTPPU: Tantangan Penegakan Hukum Pemberantasan Money Laundering (Tinjauan Hukum Pidana Materiil)", Makalah Diskusi Ammandemen UUTPPU, Jakarta 2005.

Ashe, Michael and Paula Reid, Money Laundering Risk and Liabelities, London: Round Hall, Sweet \& Maxwell, 2000.

Atmasasmita, Romli,http://korup5170.wordpress.com/opiniartikel-pakar-hukum/ urgensi- ruupengembalian aset/ diakses 9 Juni 2009.

Campbel, Enid Cs, Legal Research, Material and Method, Sidney: LBC, Information Service 1996.

Cassella, Stefan D , "The Case for Civil Forfeiture; Why in Rem Proceedings Are an Essential Tool for Recovering the Proceeds of Crime", Journal of Money Laundering Control, Vol.11.

Gilmore, William C., Dirty Money: The Evolution of Money Laundering Counterrneasures, Second Edition, revised and expanded, Belgium: Council of Europe Publishing, 2002.

Husein, Yunus, Rahasia Bank (Privasi versus Kepentingan Umum),Jakarta:Program Pascasarjana Fakultas Hukum Universitas Indonesia, 2003.

--------, Bunga Rampai Anti Pencucian Uang, Jakarta:Books Terrace \& Lirary, 2007. 
Mitsilegas, Valsamis, Money Laundering Counter-Measures in The European Union A New Paradigmof Security Governence Versus Fundamental Legal Principles, Netherland: Kluwer Law International, 2003

Noor, Azamul Fadhly, dalamhttp://www. Money Laundering., diakses, 9 Juni 2009.

Paredede, Marulak, Masalah Money Laundering di Indonesia, Jakarta: BPHN, 1994.

Sham, Alain , "Money Laundering Laws and Regulations: China and Hong Kong”, Journal Money Laundering Control, London: Vol.9, 2006.

Siahaan, NHT, Money Laundering \& Kejahataan Perbankan, Jakarta: Jala, 2008.

Sjahdeini, Sutan Remy, Seluk Beluk Tindak Pidana Pencucian Uang dan Pembiayaan Terorisme,Jakarta: Pustaka Utama Grafiti, 2004.

Smith, Ian (General editors), AssetRecovery Criminal Confiscation and Civil Recovery, UK: Lexis Nexis Butterworths, 2003

Stell, Billy "Laundring-What is Money Laundering”, p. 3-4, http:www.laundryman.u-net.com. diakses 8 Juni 2009.

Stessen, Guy, Money Laundering A New Perspective Law Enforcement Model, New York: Cambridge University Press, 2000

Sunarso, Siswanto, Ekstradisi dan Bantuan Timbal Balik dalam Masalah Pidana Instrumen Penegakan Hukum Pidana Internasional, Jakarta: Rineka Cipta, 2009.

Sutedi, Adrian, Tindak Pencucian Uang,Cetakan, Bandung: Citra Aditya Bhakti, 2008.

Triyono, Agus, "Penegakan Hukum dalam Pembangunan Rezim Anti Pencucian Uang", Makalah pada Seminar sehari tentang Peran dan Fungsi DJBC dalam Rezim Anti Pencucian Uang di Indonesia, Jakarta, 8 Desember 2004.

Utama. Paku, "Terobosan UNCAC dalam Pengembalian Aset Korupsimelalui Kerjasama Internasional", http://www.hukumonline.com/ detail. asp?id=19356\&cl=kolom, diakses 2 April 2008. 